\title{
Embedding Graduate Skills in Capstone Courses
}

\author{
Liz van Acker \\ Department of Politics and Public Policy and Centre for Governance and Public Policy \\ Griffith University \\ Nathan, Qld 4111, Australia \\ Tel: 61-7-3735-7696 E-mail: e.vanacker@griffith.edu.au
}

Janis Bailey (Corresponding author)

Department of Employment Relations and Human Resources and Centre for Work, Organisation and Well-being

Griffith University

PMB 50, Gold Coast Mail Centre, Qld 9726, Australia

Tel: 61-7-5552-7748Ｅ-mail: j.bailey@griffith.edu.au

Received: February 6, 2011 Accepted: February 23, 2011 doi:10.5539/ass.v7n4p69

This research was funded by a Teaching and Learning grant from the Griffith Business School, Griffith University, Australia. The contributions of Brona Farrelly and Ray Hibbins to that project are gratefully acknowledged.

\begin{abstract}
The purpose of this article is to explore the literature on capstone courses generally - and capstones in undergraduate business degrees in particular - to determine the role of these courses in embedding graduate skills, with specific emphasis on a study conducted by the authors and colleagues. The paper concludes by providing five core principles for embedding generic skills as a way of improving the design, teaching and assessment of capstone courses.
\end{abstract}

Keywords: Capstone courses, Business curriculum, Graduate skills

\section{Introduction}

Capstone courses are usually taken in a student's last year or semester of study. Holdsworth, Watty and Davies (2009) offer a useful definition: "The term 'capstone' is widely used to describe a course or experience that provides opportunities for a student to apply the knowledge gained throughout their undergraduate degree. This involves integrating graduate capabilities and employability skills, and occurs usually in the final year of an undergraduate degree." (p. 2)

These courses have three major functions. First, they aim to consolidate, extend and apply previous learning (Bailey, Oliver, \& Townsend, 2007; Moore, 2004; Rowles et al., 2004). Second, they provide a vehicle for professional socialisation and the development of professional identity to assist students' transition to employment (Dunlap, 2005; Kain, 1999; Lizzio \& Wilson, 2004; McKinney, Saxe, \& Cobb, 1998) and, more broadly, they may play a key role in ensuring graduates are "agents of social good in an unknown future" (Bowden et al., 2000, cited in Barrie, 2004, p. 262). Third - and related to the previous point and to the purpose of this special issue - capstone courses can be used to confirm that students have mastered what are often called "soft" or "employability" skills by the business sector (BIHECC, 2007) and graduate (or "generic") skills (or "attributes") by academics. The list of graduate skills is long and growing (Crebert et al., 2004); terminology is ambiguous (Clanchy \& Ballard, 1995, p. 155; Green, Hammer, \& Star, 2009) and inadequate (Barrie, 2004); and terminology differs between academic and employment contexts (Holmes, 2001, p. 112). Graduate skills include critical thinking, communication, information literacy, teamwork, use of technology, managing conflict, planning and decision making, personal and intellectual autonomy, and ethical, social and professional understanding (ABDC, 2008, pp. 13-14; Barrie, 2004; Crebert et al., 2004; Payne, Whitfield, \& Flynn, 2002; Redmond, 1998; Rychen \& Salganik, 2001). Some "skills" 
like creativity and intellectual curiosity (Bath et al., 2004) are less likely to appear in lists of desirable attributes than others.

Capstone courses are both a "synthesis - reflection and integration - and a bridge - a real-world preparatory experience that focuses on the postgraduation future." (Fairchild \& Taylor, 2000, and Rhodus \& Hoskins, 1995, cited in Kerka, 2001, p. 3) They look backwards, to students' prior learning; and forwards, to their future jobs and careers and, for that reason, are an academic rite of passage (Durel, 1993, p. 223). These courses are the last step from novice to expert; but a crucial step, as it is often the last opportunity for university education to add value to the students' learning (Gardner, 1998, p. 6).

The purpose of this article is to explore the literature on capstone courses generally, and capstones in undergraduate business degrees in particular, to determine the role of these courses in embedding graduate skills. To give a wider context, the article discusses types of capstones and the current higher education environment, which is placing more emphasis on capstone experiences. The article then reviews the literature on capstone courses, to determine to what extent capstone courses are argued to be (and actually are) sites for embedding graduate skills, with particular emphasis on a study conducted by the authors and colleagues. The paper concludes by presenting five core principles for embedding generic skills as a way of improving the design, teaching and assessment of capstone courses.

\section{Types of capstone experiences in business degrees}

Capstone experiences include formal courses, seminars, independent projects, industry internships and study-abroad programs, many of which come under the rubric of Work Integrated Learning (WIL) and/or involve out-of-class activities. As much has been written on WIL, this paper focuses on primarily campus-based formal courses and seminar formats (which may involve some activities off campus).

In Australian undergraduate business programs, the overwhelming majority of capstones are "magnets" within a major, "pulling together the richness of content from the discipline" (Rowles et al., 2004, p. 13; van Acker et al., 2009a). Macquarie University (Macquarie University, 2011) and Queensland University of Technology (QUT, 2011) have suites of such magnets in undergraduate business programs; for Macquarie, capstone courses are a university-wide strategy. A few Australian business schools incorporate "mountaintops" that offer interdisciplinary projects in which students in different majors work together; Wollongong will introduce such courses into their undergraduate business curriculum in 2011 (University of Wollongong, 2011). Others, such as Griffith University, have capstones in some business programs but not others (Griffith University, 2011). Some may only be capstones in name, if lecturers have no understanding of what a capstone is, and/or if institutional processes to develop capstones are not rigorous (van Acker et al., 2009a, p. 11). Indeed, most Australian business capstones would not meet some rigorous definitions as they are not truly multidisciplinary, and may omit factors such as cultural congruence and appreciation of broader systems issues (Schroetter \& Wendler, 2008, p. 76).

Commonly, business capstones take a strategic management perspective (Payne, Whitfield, \& Flynn, 2002, p. 69) and may involve business simulations in which students run a virtual - or actual - small start-up company (Steiner \& Wells, 2000; Kachra \& Schnietz, 2008) and analysis of strategy cases (Kachra \& Schnietz, 2008; Garvin, 2003). Most capstone assessment requires some kind of project, which can be client-sponsored (that is, with direct involvement of an organisation in setting the parameters of the project and providing data) or may attempt to simulate a workplace issue. Project-based learning involves attempts to move to more authentic forms of learning, similar to what students would encounter in the workplace. Other types of common learning and assessment activities in capstone courses similarly call for the application of a wide range of generic skills. For instance, problem-based learning (Hmelo-Silver, 2004) involves a real or simulated set of circumstances, while case study analysis (Ellet, 2007) focuses on participant learning based on specific cases. Core learning activities in capstones are diverse within institutions; for instance, in one institution, the marketing capstone uses a computer-simulation marketing-strategy game; the politics capstone has students preparing, presenting and critiquing Cabinet submissions; and the employment relations capstone requires students to prepare an employment relations plan for an organisation, taking into account implementation and evaluation issues (van Acker et al., 2009a).

While the single-course, final-semester model appears to be the most common version, alternative approaches include multi-level capstones offered in each year of a degree, differing in objectives and activities as students progress through the program (Collins \& Dunne, 1996). Occasionally pre-capstone courses are offered, which encourage students to identify and pursue their own interests and practice some of the skills necessary as well as to hear from more advanced students who have previously completed internships (Wattiaux, 2006). Dual capstones can be offered, that is, two complementary capstones; one course may be on-campus, focus on current 
issues, and result in a research-based group project; while the other may be worksite based, allowing the student to demonstrate an understanding of the complexity of issues within the student's area of practice (Schroetter $\&$ Wendler, 2008, pp. 74-75).

In Australian business schools, 60 per cent of schools have at least some capstone courses (van Acker et al., 2009a). However, only a few universities have magnet capstones in all business majors and/or a mountaintop capstone in all degrees.

\section{The context for change and development in capstone courses}

Capstone courses can serve multiple objectives that go beyond student learning, objectives that have national and even international implications. At an institutional level, capstones form a key plank in broad, holistic measurement of the achievement of program learning goals, so-called "macro-assessment", in contrast to "micro-assessment" which focuses on the measurement of specific content and/or skills (Redmond, 1998, p. 72), although capstones can do both. They can be used by outside bodies for mandatory assurance of learning, and as part of optional accreditation processes such as those run by the US-based Association to Advance Collegiate Schools of Business (AACSB) and the European Quality Improvement System (EQUIS). From a national perspective, Australian universities have hitherto been self-accrediting, with only light-touch quality assurance procedures, but the recent creation of the Tertiary Education Quality Standards Agency (TEQSA) will place more pressure on externally developed standards, and external moderation of courses and programs. In view of these moves, the Australian Learning and Teaching Council's "Learning and Teaching Academic Standards Project" has released standards for accounting and other business disciplines will be considered soon (ALTC, 2011). As part of the increasing practice and discourse of external regulation of quality and standards, capstones - and other aspects of students' final-year experience - will come under increasing pressure to deliver assurance of learning.

\section{Capstone courses and graduate skills: the literature}

We know a good deal about how a capstone course should be taught from the literature, but much less about what capstone lecturers actually do teach and the impact upon students. Despite this normative advice, there are few analytical or empirical studies. However, the literature suggests that capstone courses are a prime locus to consolidate graduate skills. We emphasize "consolidate" as it is important to recognize that universities need to take a layered or staged development approach to the development of generic skills (Barrie, 2004, p. 267), so that skill development is integrated across the curriculum (de la Harpe, Radloff, \& Wyber, 2000, p. 234). Generic skills are too multi-layered and complex to simply be taught in one or even a few courses.

The literature on capstone courses suggests there is a distinctive cluster of approaches to teaching a capstone, including:

- Limited introduction of new conceptual/theoretical material

- Less formal class contact time, particularly lectures

- Assessment designed in stages to allow for formative feedback

- Group work, but with a component of individual assessment (in order to assure individual learning and promote reflectivity)

- Multiple ways of presenting the same information (for example, a written report, and an extract of one issue or recommendation as an oral presentation)

- Formal and informal contact with practitioners, for example as formal guest lecturers or research informants

- Team teaching, both as a model of collaborative approaches, and to draw on diverse staff skills

- A variety of pedagogical approaches based on diverse learning styles.

(adapted from Bailey, Oliver, \& Townsend, 2007, p. 67).

While none of these approaches is exclusive to a capstone, more of these are likely to be used, and more intensively, than in other courses (ibid, p. 67).

There is little rigorous empirical literature on capstones that goes beyond anecdote, beyond a single course, and/or involves the systematic collection of data (even from a single course). Student data comes from a few, mostly single-course studies. Jarman and Willey (2007) showed that engineering students undertaking authentic industry-based projects scored higher across a range of graduate skills, including "professional attitudes" and "understanding the business environment", than did students undertaking faculty-devised, more artificial projects. 
Dunlap (2005) measured the changes in self-efficacy of students in a software engineering capstone, finding a dramatic increase in mean self-efficacy scores from 22 pre-semester to 38 post-semester (with the maximum possible being 40). Self-efficacy is arguably related to graduate skill development in that presumably feeling competent to tackle workplace tasks is a measure of confidence in one's generic skills as well as one's knowledge. Replicating aspects of Dunlap's study, Bailey, Oliver and Townsend (2007) found no significant increase in self-efficacy for students who had done employment relations capstones, although the students whose scores increased the most were those with the lowest pre-semester scores - they reached average scores by the end of the semester. In any case the initial baseline scores were high, and a large proportion of the cohort had already had paid or unpaid work experience. While there are broad-ranging studies of graduates' and employers' perceptions of whether they have developed graduate skills, no literature specifically explores the particular role of capstone courses in this process.

Some studies have gathered data from staff. Nilsson and Fulton (2002) surveyed a small number of lecturers in three countries (14 usable responses) regarding capstones in agriculture programs. They showed that lectures averaged just over 30 per cent of course time, while projects, presentations and case studies took up more than 50 per cent of course time, with the four most important learning objectives and student outcomes being the graduate skills of communication, problem solving, knowledge and skill utilisation, and problem identification. Hauhart and Grahe's (2010) survey of 95 sociology and psychology staff teaching capstone courses in the US investigated the stated purposes and characteristics of capstone courses or "senior seminars" in order to capture their most common features. Characteristics investigated included assessment regimes, learning activities and staffing (for example, whether team teaching was used). The study did not seek data, however, about the embedding of graduate attributes.

Therefore, there are considerable gaps and limitations in the literature. Many of the studies are of single courses (Bailey, Oliver, \& Townsend, 2007; Dunlap, 2005; Jarman \& Willey, 2007; Keller, Chan, \& Parker, 2010); have small sample sizes (Udlis, 2008; Nilsson \& Fulton, 2002); cover more superficial features of course design and assessment (Hauhart \& Grahe, 2010); and have other methodological problems (Udlis, 2008). As the studies have been mostly based on perceptions, the surveys have been better at assessing affective issues (see for example Rebeschi \& Aronson, 2009) than providing objective evidence on attainment of graduate skills (see for example Wattiaux, 2006), although it is argued that self-reporting is a valuable way of measuring aspects of students' academic development (Tapper, 2004). There are few opportunities to conduct controlled studies, and there have been few comparative studies that have gathered data from more than one course.

\section{Capstone courses and graduate skills: a case study of capstone lecturers in one business school}

A unique study of staff teaching associated with capstones is that of van Acker et al. (2009a; 2009b) dealing with magnet capstones within a single business school, in which 11 capstone course convenors and seven program directors were interviewed. The embedding of generic skills was one aspect covered. The study found that even within a single business school, strategies were very diverse, were guided by diverse conceptions of what a capstone does, and approached course design, content, assessment and skills in very different ways. This is unsurprising and is consistent with the literature on capstones, which does not advocate a one-size-fits-all model.

The interviewees were provided with a graduate skills table as set out in the university's program learning objectives and asked to identify which skills were covered, and how. Problem solving, teamwork, critical thinking and communication skills were mentioned consistently as important and necessary skills for graduates. This accords with a comprehensive review of the capstone literature that found that such courses include improved collaboration skills, heightened critical thinking skills, and enhanced professional development skills (Schroetter \& Wendler, 2008, p. 74, and the studies cited therein; Nilsson \& Fulton, 2002). Van Acker et al.'s study (2009a) bears out Holdsworth, Watty and Davies' (2009) contention that capstone courses are a key method of embedding and assessing graduate skills in a student's program of study (p. 6). The course conveners in van Acker et al.'s audit agreed that capstone courses integrated both knowledge and generic skills from other courses in the major in which they were teaching. Indeed, many conveners deliberately devised learning activities and assessment strategies that were very different to previous courses studied by students in the major. They also attempted to simulate tasks which new graduates could be expected to complete in the workplace.

Conveners sought not only to fulfill the mission of capstones to integrate knowledge, but pursued a deliberate strategy of integrating a variety of generic skills. The assumption appeared to be that the student had advanced discipline knowledge and therefore could be examined by complex, integrative assessment items underpinned by complex notions of graduate skills. Again, this is consistent with the literature that generic skills are an interwoven network of a variety of attributes and skills and can usefully be assessed in a single, authentic assessment item, as 
opposed to disconnected "functional, atomistic, personal skills" (Barrie, 2004, p. 266). Embedding more complex notions of graduate skills in course design in advanced courses such as capstones means skills are more likely "to outlast the knowledge and contexts in which they were originally applied (ibid, p. 265), and thus are more transferable. For many of the conveners, however, the treatment of skills was tacit rather than explicit, with conveners (ideally) expecting students to have mastered them, but fully aware this was not necessarily the case.

Lecturers in the business school where van Acker et al.'s study took place faced a number of challenges, in particular the size and format of classes, with most of the courses constrained by a two-hour lecture plus one-hour-tutorial time slots with very large student numbers (some in excess of 200 students). Such resource constraints militated against more active, diverse, experiential learning and teaching activities that incorporate high levels of teacher-student and student-student interaction in a socially integrated learning environment. The latter mode is much more effective in developing graduate skills than lecture-based teaching (Candy, 2000, cited in Smith \& Bath, 2006, p. 262; Kember \& Leung, 2005; Smith \& Bath, 2006). In addition, particularly where courses took a strategy perspective, several interviewees reported a tension between the prescriptions of the literature about no (or little) new content, since courses the student had done previously in the major often had not covered strategic management concepts to any appreciable extent. Covering new content necessarily deflected attention from complex, integrated skills development, as students were coming to terms with new and difficult concepts. Finally, some lecturers reported not knowing what a capstone was; in some cases, an existing course had been renamed as a capstone during a program review, but no changes were made to ensure the course actually became a capstone. Hence this study showed that lecturers incorporated a range of generic skills in capstone courses in innovative ways, but at times were unsure of how to deal with skills deficits in the students, and faced institutional constraints such as conventional timetabling strictures and large class sizes.

\section{Principles to embed generic skills in capstone courses}

Drawing on the authors' previous work (Bailey, Oliver, \& Townsend, 2007; van Acker et al., 2009a; 2009b) and the literature surveyed above, we have developed five core principles for embedding generic skills in capstone courses:

- Some existing and well-documented features of capstone courses are particularly useful for embedding generic skills. Any approach that encourages experiential, active, authentic approaches that approximate (or actually are) real-world problems are ideal. Such typical features in capstones would include less emphasis on formal lecturing, as well as more project-based assessment, and other issues listed earlier in this paper.

- Capstone courses attempt to develop independence in students, which can create uncertainties and ambiguities for them, as well as challenges for the lecturer (Bailey, Oliver, \& Townsend, 2007; van Acker, $2009 \mathrm{~b}$ ) who must respond with an appropriate mix of scaffolding and provide (or decide it is inappropriate to provide) lifebelts for students in given contexts (Bailey, Oliver, \& Townsend, 2007, p. 68). This applies to the embedding of generic skills as well as the integration of knowledge.

- Some skills are better developed at university; others in the workplace. One study found that communication, problem solving, analysis and teamwork are in the first category; and leadership and entrepreneurial skills, assuming responsibility and making decisions, and issues of ethics are in the second (Crebert et al., 2004). Thus the development of some generic skills may best be left for work-integrated learning, graduate jobs, or postgraduate study, rather than in the undergraduate curriculum. Staff will have to make choices about this issue.

- There needs to be explicit connections made between the various parts of the curriculum, both within the capstone and within the major or program. The aim is to make strong links between what students are learning in the classroom - including its generic component - and its practical application in the workplace (Crebert et al., 2004, p. 158). Skills of transfer - "learning how to learn, awareness of contact, capacity to move between different viewpoints, languages and systems of knowledge, self-regulation and critical self-reflection" (Marginson, 1994, cited in Crebert et al., 2004, p. 161) - may enhance generic skills development and this is more likely to occur in more advanced courses such as a capstone. Putting together a portfolio of material (drawn from other courses, as well as the capstone) may be one strategy that allows students to reflect on - and demonstrate for outsiders - their employability skills.

- Individual staff, working independently, cannot be expected to achieve significant improvements in embedding graduate skills (de la Harpe, Radloff, \& Wyber, 2000, p. 239), even in capstone courses with advanced students. Further, while the processes involved in curriculum mapping can produce effective results, narrowly technicist, uncritical approaches to change may be counterproductive (Sumsion \& 
Goodfellow, 2004). For capstone courses, this will mean conversations about what graduate skills development occurs in courses prior to the capstone, and what students can be relied on to know and do once they reach the capstone. Such conversations must begin with the university's statement of graduate skills, reframed collaboratively within a disciplinary context (see Jones, 2009).

\section{Conclusion}

We plan to undertake further research to explore in more detail the role of capstone courses in undergraduate business degrees in Australia. (Note 1) The available evidence shows that staff are often unaware of the purpose of capstone courses, and may not understand that they are radically different from other courses and thus require different pedagogies. Further, staff are at times confused and unsure about their role in producing graduates with professional skills. However, capstone courses are a key strategy for embedding graduate skills in the undergraduate business curriculum. Thus close attention needs to be paid - sector-wide, institutionally, at program level and course level - in order to heighten awareness of such courses, and of their key role in embedding graduate skills.

\section{References}

ABDC. (2008). Business as usual: a collaborative and inclusive investigation of existing resources, strengths, gaps and challenges to be addressed for sustainability in teaching and learning in Australian university business faculties. Australian Business Deans Council/Carrick Institute, March 2008.

ALTC. (2011). Learning and teaching academic standards project overview. [Online] Available: www.altc.edu.au/standards/overview (January 5, 2011).

Bailey, J., Oliver, D., \& Townsend, K. (2007). Transition to practitioner: redesigning a third year course for undergraduate business students. Journal of Management and Organization, 13(1), 65-80.

Barrie, S. (2004). A research-based approach to generic graduate attributes policy. Higher Education Research and Development, 23(3), 262-275.

Bath, D., Smith, C., Stein, S., \& Swann, R. (2004). Beyond mapping and embedding graduate attributes: bringing together quality assurance and action learning to create a validated and living curriculum. Higher Education Research and Development, 23(3), 313-328.

BIHECC. (2007). Graduate employability skills. Prepared for the Business, Industry and Higher Education Collaboration Council by Precision Consultancy. [Online] Available: www.dest.gov.au (November 23, 2009).

Clanchy, J. \& Ballard, B. (1995). Generic skills in the context of higher education. Higher Education Research and Development, 14(2), 155-166.

Collins, R. \& Dunne, A. (1996). Utilizing multilevel capstone courses in an integrated agribusiness curriculum. Agribusiness, 12(1), 105-112.

Crebert, G., Bates, M., Bell, B., Patrick, C., \& Cragnolini, V. (2004). Developing generic skills at university, during work placement and in employment: graduates' perceptions. Higher Education Research and Development, 23(2), 147-165.

de la Harpe, B., Radloff, A., \& Wyber, J. (2000). Quality and generic (professional) skills. Quality in Higher Education, 6(3), 231-243.

Dunlap, J. (2005). Problem-based learning and self-efficacy: how a capstone course prepares students for a profession. Educational Technology, Research and Development, 53(1), 65-85.

Durel, R. (1993). The capstone course: a rite of passage. Teaching Sociology, 21(3), 223-225.

Ellet, W. (2007). The case study handbook: how to read, discuss and write persuasively about cases. Boston, MA: Harvard Business School Press.

Gardner, P. (1998). Are college seniors prepared to work? In J. Gardner, \& C. van der Veer \& Associates (Eds.), The senior year experience: facilitating integration, reflection, closure and transition. San Francisco, CA: Jossey-Bass Inc.

Garvin, D. (2003). Making the case: professional education for the world of practice. Harvard Magazine, 106(1), 56-65, 107.

Green, W., Hammer, S., \& Star, C. (2009). Facing up to the challenge: why it is so hard to develop graduate attributes? Higher Education Research and Development, 28(1), 17-29.

Griffith University. (2011). Bachelor of Business and Bachelor of Commerce degree structures. [Online] 
Available:

Commerce\&level $=$ Undergraduate $\&$ display $=$ open $($ January 4, 2011).

Hauhart, R. \& Grahe, J. (2010). The undergraduate capstone course in the social sciences: results from a regional survey. Teaching Sociology, 38(1), 4-17.

Hmelo-Silver, C. E. (2004). Problem-based learning: what and how do students learn? Educational Psychology Review, 16(3), 235-266.

Holdsworth, A., Watty, K., \& Davies, M. (2009). Developing capstone experiences. Melbourne: Centre for Study of Higher Education, University of Melbourne.

Holmes, L. (2001). Reconsidering graduate employability: the 'graduate identity' approach. Quality in Higher Education, 7(2), 111-119.

Jarman, R. \& Willey, K. (2007). Benchmarking capstone projects in UTS Faculty of Engineering. Paper presented at Research and development in higher education: Reshaping higher education conference, 33rd HERDSA Annual International Conference, July 6-9, 2010. Melbourne, pp. 45-50.

Jones, A. (2009). Redisciplining generic attributes: the disciplinary context in focus. Studies in Higher Education, 34(1), 85-100.

Kachra, A. \& Schnietz, K. (2008). The capstone strategy course: what might real integration look like? Journal of Management Education, 32(4), 476-508.

Kain, E. (1999). Building the sociological imagination through a cumulative curriculum: professional socialisation in sociology. Teaching Sociology, 27(1), 1-16.

Keller, S., Chan, C., \& Parker, C. (2010). Generic skills: do capstone courses deliver? Paper presented at Research and development in higher education: Reshaping higher education conference, 33rd HERDSA Annual International Conference, July 6-9, 2010, pp. 383-393.

Kember, D. \& Leung. (2005). The influence of active learning experiences on the development of graduate capabilities. Studies in Higher Education, 30(2), 155-170.

Kerka, S. (2001). Capstone experiences in career and technical education. Clearinghouse on Adult, Career, and Vocational Education, Practice Application Brief No. 16, 3-4.

Lizzio, A. \& Wilson, K. (2004). Action learning in higher education: an investigation of its potential to develop professional capability. Studies in Higher Education, 29(4), 469-488.

Macquarie University. (2011). Bachelor of Commerce degree structure. [Online] Available: www.courses.mq.edu.au/public/view/2011/Undergraduate/Degree/Bachelor+of+Commerce\#WhatYouWillStudy (January 4, 2011).

McConnell, C., Hoover, G.., \& Miller, G. (2008). Course embedded assessment and assurance of learning: examples from business disciplines. Academy of Educational Leadership Journal, 12(3), 19-34.

McKinney, K., Saxe, D., \& Cobb, L. (1998). Are we really doing all we can for our undergraduates? Professional socialisation via out-of-class experiences. Teaching Sociology, 26(1), 1-13.

Moore, R. (2004). The capstone course. In W. Christ (Ed.), Assessing media education: a resource for educators and administrators. Pennsylvania: Elizabethtown College.

Nilsson, T. \& Fulton, J. (2002). The capstone experience course in agricultural curriculum. Paper presented at the annual meeting of the American Agricultural Economics Association (now the Agricultural and Applied Economics Association), July 28-31, 2002. Long Beach, CA. [Online] Available: http://ageconsearch.umn.edu/bitstream/19582/1/sp02ni01.pdf (December 29, 2010).

Payne, S., Whitfield, J., \& Flynn, J. (2002). Assessing the business capstone course through a method based on the SOTL and the stakeholder process. Journal of Education for Business, 78(2), 69-74.

Queensland University of Technology. (2011). Bachelor of Business degree structure. [Online] Available:www.courses.qut.edu.au/cgi-bin/WebObjects/Courses.woa/wa/selectMajorFromMain?pres=sf\&courseI $\mathrm{D}=13511$ (January 4, 2011).

Rebeschi, L. \& Aronson, B. (2009). Assessment of nursing student's [sic] learning outcomes and employment choice after the implementation of a senior capstone course. International Journal of Nursing Education Scholarship, 6(1), 1-15. 
Redmond, M. (1998). Outcomes assessment and the capstone course in communication. The Southern Communication Journal, 64(1), 68-75.

Rowles, C., Koch, D., Hundley, S., \& Hamilton, S. (2004). Toward a model for capstone experiences: mountaintops, magnets, and mandates. Progress, Trends and Practices in Higher Education, 16(1), 1-2, 13-15.

Rychen, D. \& Salganik, L. (2001). Defining and selecting key competencies. Gottingen: Hogrefe and Huber.

Schroetter, S. \& Wendler, M.C. (2008). Capstone experience: analysis of an educational concept for nursing. Journal of Professional Nursing, 24(2), 71-79.

Smith, C. \& Bath, D. (2006). The role of the learning community in the development of discipline and generic graduate outcomes. Higher Education, 51(2), 259-286.

Steiner, T. \& Wells, M. (2000). Integration of the business curriculum: the case of finance and marketing in an MBA program. Financial Practice and Education, 10(2), 148-159.

Sumsion, J. \& Goodfellow, J. (2004). Identifying generic skills through curriculum mapping. Higher Education Research and Development, 23(3), 329-346.

Tapper, J. (2004). Student perceptions of how critical thinking is embedded in a degree program. Higher Education Research and Development, 23(2), 199-222.

Udlis, K. (2008). Preceptorship in undergraduate nursing education: an integrative review. Journal of Nursing Education, 47(1), 20-29.

University of Wollongong. (2011). Bachelor of Commerce degree structure. [Online] Available: www.uow.edu.au/handbook/yr2010/ug/commerce/H10006744.html (January 4, 2011).

van Acker, E., Bailey, J., Farrelly, B., \& Hibbins, R. (2009a). Capstone course audit. Brisbane: Griffith Business School.

van Acker, E., Bailey, J., Farrelly, B., \& Hibbins, R. (2009b). Capstone courses: the challenges of enhancing student engagement. Unpublished paper presented at 2009 HERDSA conference.

Wattiaux, M. (2006). Preparing sophomores for independent learning experiences with a pre-capstone Seminar. North American Teachers and Colleges of Agriculture Journal, September, 19-25.

Note

Note 1. To be funded by ALTC Priority Program Grant PP10-1646 "Capstone courses in undergraduate business degrees: better course design, better learning activities, better assessment", with colleagues Lorelle Frazer, Jacqui Fyffe, Ray Hibbins and Keithia Wilson (Griffith University); David Gray and Leigh Wood (Macquarie University); Lynda Andrews and Erica French (Queensland University of Technology); Johanna Macneil and Jim Psaros (University of Newcastle); and Jan Turbill and Michael Zanko (University of Wollongong). 